University of South Carolina

Scholar Commons

6-1985

\title{
Wealth and Migration in Massachusetts and Maine: 1771-1798
}

John W. Adams

University of South Carolina - Columbia, jwadams0@mailbox.sc.edu

Alice Bee Kasakoff

Follow this and additional works at: https://scholarcommons.sc.edu/anth_facpub

Part of the Anthropology Commons

\section{Publication Info}

Journal of Economic History, Volume 45, Issue 2, 1985, pages 363-368.

(C) Journal of Economic History 1985, The Economic History Association.

This Article is brought to you by the Anthropology, Department of at Scholar Commons. It has been accepted for inclusion in Faculty Publications by an authorized administrator of Scholar Commons. For more information, please contact digres@mailbox.sc.edu. 


\title{
Wealth and Migration in Massachusetts and Maine: $1771-1798$
}

\author{
John W. Adams and Alice Bee Kasakoff
}

\begin{abstract}
We use a genealogical data base to question the idea that the frontier was a "safety valve" for Americans in the years of the founding of the republic. Our findings about the relative wealth of members of nine families show how the frontier affected their migration patterns. We find that it was the middle class, not the poor, who seemed to make best use of the opportunity of the frontier.
\end{abstract}

$\mathbf{T}$ THE idea that the American frontier provided an opportunity for the poor in America to better themselves is so persuasive that attempts to disprove it have had little effect, even though, by general consent, the United States was socially and economically stratified when it is thought the frontier closed in the 1890s. As data have become available, earlier periods have also been found less egalitarian than presumed. Yet recently Douglas Jones, writing of New England villages in the 1780s and 1790s, has again postulated the safety-valve theory. ${ }^{1}$

For the past few years, we have been following the migrations of nine New England families whose ancestors first came to Massachusetts before 1650. Our sources, published genealogies, are used to answer questions about how often each of the men moved, at what points in the life cycle, and the distance traveled each time. The families were chosen for the quality of the information. To ensure coverage of all of Massachusetts, we used three geographical regions: the North Shore, the Boston area and the South Shore and chose three families who had

Journal of Economic History, Vol. XLV, No. 2 (June 1985). (C) The Economic History Association. All rights reserved. ISSN 0022-0507.

The authors are members of the Department of Anthropology, University of South Carolina, Columbia, South Carolina 29208. The research for this paper was funded by an NEH fellowship administered through the Newberry Library, a University of South Carolina Faculty Research Grant, and grants from the National Science Foundation's Geography and Regional Sciences Program (SES \#8016384), their Anthropology Program (BNS \#8305214), and their EPSCOR program. The data from the 1771 Massachusetts Tax Valuation Records were made available by the Inter-university Consortium for Political and Social Research. They were originally collected by Bettye Pruitt. Neither the original collector nor the consortium bears any responsibility for the analyses or interpretations presented here. We would also like to thank the following people for their help and comments: David Davenport, Stanley Engerman, Kirby Jackson, Kim Kelly, Peter Knights, Jessica Kross, Gloria Main, Robert Margo, Debra Martin, Sara Mascia, S. Rajendron, Jimmy Roberts, and Tom Sims.

${ }^{1}$ Douglas Jones, Village and Seaport (Hanover, N.H., 1981). See a $\rightarrow$ Jeremy Atack, "Farm and Farm-Making Costs Revisited," Agricultural History, 56 (Oct. 1982), pp. 663-76; Clarence Danhof, "The Farm Enterprise: the Northern United States, 1820-1860's," in Paul Uselding, ed., Research in Economic History (Greenwich, Conn., 1979). 
originally settled in each area. The data are well-suited to test Jones' suggestion. ${ }^{2}$

We began by listing the 307 male patrilineal descendants alive in 1771, the year of a tax valuation list of households in Massachusetts and Maine which reported estimates of yearly income from real property. ${ }^{3}$ Nearly 40 percent were living in other colonies-notably New Hampshire and Connecticut-so the number of potential finds was 188 , a group of essentially the more stay-at-home relatives even though they were seldom living exactly where their ancestors first settled. We found 104 listed as household heads. Of those not found, most were either too young to be heads of households or were living in towns for which the valuation lists are missing.

\section{THE DATA BASE}

Our families were poorer than the tax list as a whole. Mean yearly income from real property of the households on the 1771 list was 1222.9 pence; for our group it was only 971.0 pence, or 79 percent. The reason is that our group lacks the top 5 percent of the income distribution (over 4800 pence). The wealthy were concentrated in commercial centers, but the families we are studying were not; only 5 percent of our family members were living in Boston, Salem, Gloucester, or Bridgewater, while 13 percent of the entire tax list lived in those towns. However, the median wealth of our group ( 720 pence) falls above the median of the tax list (600 pence) because our group contains fewer people with zero income. Only 19 percent of our group had a zero-pence valuation, while 27 percent of the list is so valued. Most of those with no income from real property, such as sailors, were also living in the coastal towns.

To estimate the chance that a sample such as ours might have been drawn from the 1771 list at random, we drew nine random samples from the list. All nine included people in the top 5 percent of the income distribution. Thus the random samples all had higher mean incomes than our group. In four of the nine samples the difference was significant, but being in our group rather than being chosen at random

\footnotetext{
2 The nine genealogies used in this paper are: Frank J. Bisbee, Genealogy of the Bisbee Family (East Sullivan, N.H., 1956); William Chaffee, The Chaffee Genealogy (New York, 1909); Mary Lovering Holman, Ancestors and Descendants of John Coney of Boston, England and Boston, Massachusetts (Concord, N.H., 1928); J. D. Farwell, The Farwell Family (Orange, Texas, 1929); James Freer Faunce, The Faunce Family: History and Genealogy (Akron, Ohio, 1973); G. H. Greely, Genealogy of the Greely-Greeley Family (Boston, 1905); J. M. Pelton, Genealogy of the Pelton Family in America (Albany, N.Y., 1892); Frank E. Shedd, Daniel Shed Genealogy (Boston, 1921); Joshua Wyman Wellman, Descendants of Thomas Wellman of Lynn, Massachusetts (Boston, 1918).

${ }^{3}$ Bettye Hobbs Pruitt, ed., The Massachusetts Tax Valuation List of 1771 (Boston, 1978). The list, in machine readable form, is available from The Inter-university Consortium for Political and Social Research.
} 
explained only 2 to 3 percent of the variance. The difference, in other words, is not very important. So we conclude that our group is a useful sample of the population at large, except that it contains fewer representatives of the extremes.

Next we arbitrarily established three categories of income for our group: the lowest quartile we called poor, the highest rich, and the 50 percent in-between middling for each ten-year age cohort.

We had to modify the assignments somewhat. We classified a few men as rich who had considerable amounts of stock in trade and money at interest, even though their incomes from real property did not fall in the highest quartile, and we decided to eliminate those in their twenties and thirties with zero valuations if their fathers were still alive and not poor, thus eliminating those who were poor simply because they were awaiting an inheritance. (The death of the household head's father added almost 500 pence to a man's estimated income no matter what the age of the son when his father died.) We considered those over 60 with zero valuations to be genuinely poor only if they had sons on the list who were also poor. There was only one such case. Those with zero valuations who did not meet these criteria are not included in the results we present. ${ }^{4}$

\section{PATTERNS OF MOVEMENT}

Men in the three income groups had different patterns of lifetime movement as measured by distance from birthplace to place of death. Stayers were 49 percent of the entire group, but among the wealthy, 62 percent spent their entire lives near their birthplaces. The movements of the bottom 25 percent are confined to a relatively small radius. The middlers, on the other hand, have both the fewest stayers and do the most traveling over 100 miles. No poor person traveled that far, and the middling rate is three times that of the rich. Was this simply a one-time pattern or did it persist?

To answer the question we traced family members to the 1798 valuation list to find the direct tax on real property. Then we divided them as before into wealth categories by age..$^{5}$ The period directly following the Revolution was one of unusual geographic movement and contained an increased number of long distance moves. In the families we are studying the average distance traveled from birth to death

\footnotetext{
${ }^{4}$ Income rises with the age of the household head until he reaches his sixties because there are usually increasing numbers of sons contributing to the family's income. When zero incomes are excluded and income is logged to the base 10 , the number of rateable polls accounts for 14 percent of the variance in incomes in our sample. But age alone explains only 3 percent, and when both age and polls are included in the equation, age is less important.

${ }^{5}$ Michael H. Gorn, ed., Massachusetts and Maine Direct Tax Census of 1798 (Boston, 1979), on microfilm.
} 


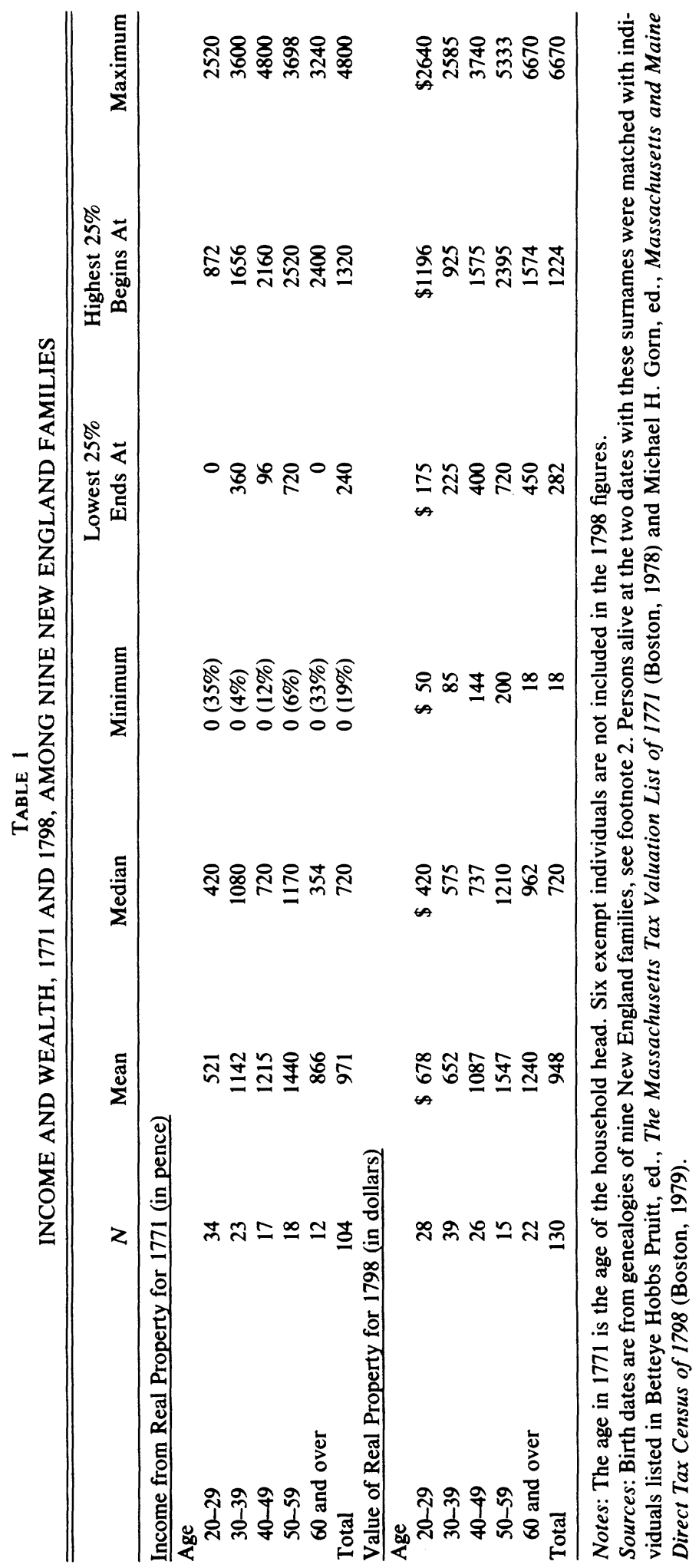


TABLE 2

DISTANCES MIGRATED OVER LIFETIMES

AMONG MALE DESCENDANTS OF NINE NEW ENGLAND FAMILIES

\begin{tabular}{|c|c|c|c|c|c|c|c|}
\hline & $N$ & Mean & Median & $\begin{array}{c}\text { Fewer } \\
\text { than } 4 \\
\text { Miles }\end{array}$ & $\begin{array}{c}4 \text { to } 15.9 \\
\text { Miles }\end{array}$ & $\begin{array}{c}16 \text { to } 99.9 \\
\text { Miles }\end{array}$ & $\begin{array}{l}100 \text { plus } \\
\text { Miles }\end{array}$ \\
\hline \multicolumn{8}{|c|}{ Men on 1771 List } \\
\hline Rich & 29 & 19.4 & 0 & $62 \%$ & $7 \%$ & $24 \%$ & $7 \%$ \\
\hline Middling & 48 & 43.8 & 10.2 & 40 & 21 & 19 & 21 \\
\hline Poor & 20 & 8.0 & 1.9 & 55 & 30 & 15 & .0 \\
\hline Total & 97 & 29.1 & 5.5 & 49 & 19 & 20 & 12 \\
\hline \multicolumn{8}{|c|}{ Men on 1798 List } \\
\hline Rich & 34 & 55.6 & 7.4 & $38 \%$ & $26 \%$ & $12 \%$ & $26 \%$ \\
\hline Middling & 63 & 86.1 & 40.0 & 25 & 16 & 19 & 40 \\
\hline Poor & 33 & 54.7 & 7.1 & 42 & 21 & 12 & 24 \\
\hline Total & 130 & 70.1 & 15.3 & 33 & 20 & 15 & 32 \\
\hline
\end{tabular}

Notes: These are net distances in miles between the first and last places on the individual's record. Moves of fewer than 4 miles usually represent changes of town names due to subdivision, so we can combine the very short distance movers with those who did not move at all. In 1771,85 percent were covered from birth to death. The others were lost at an average age of 53. In 1798, 80 percent were covered from birth to death. The rest were lost at an average age of 48 .

Sources: See Table 1. Migration distances are from residential information on the genealogies.

increased threefold. Men alive in 1771 traveled 13.7 miles; those alive in 1798, 33.8 miles. Even those who stayed at home (still in Massachusetts and Maine whom we found on the lists) more than doubled the distance they traveled in a lifetime.

Both poor and rich went farther than before, yet the differences between social classes are still visible. The middling group continued to predominate over long distances; the proportion of middlers who moved over 100 miles was half again as much as for rich or poor. Rich and poor patterns are now quite similar: both are more likely to stay close to their birthplaces than the middle group. ${ }^{6}$

\section{DISCUSSION}

Our data suggest that those fifth and sixth generation inhabitants who left the older parts of Massachusetts and Maine were not poor; nor were they pioneers. Only two of the migrants in our group could be considered town founders; the rest arrived when the destination towns were more than twenty-five years old. Many people in our families went to younger towns in this period, but they did so from New Hampshire, Connecticut and Vermont, not Massachusetts and Maine. For the people in the oldest areas, at least, the frontier was not a safety valve.

\footnotetext{
6 These findings remain the same even if we remove from our calculations the twenty-three people who appear on both lists.
} 
The poorest could not afford to go and the richest did not have to go.

By the eve of the Revolution, then, a stratum of comparatively poor people had crystallized in Massachusetts and Maine who were restricted in their opportunities to move the long distances to reach the cheaper land on the frontier. Perhaps as many as 25 percent of the population were so restricted at the time. Yet there was opportunity for mobility for at least 50 percent of the people. Presumably those closer to the frontier had still greater opportunity. Moving entailed costs, and there was an evident threshold to them. From older areas it was the middlers who were most apt to go the 100 miles or more necessary to take advantage of the opportunity which the frontier offered. With the opening of new lands after the Revolution more of the poor were able to travel long distances, but the middle group was more likely to do so.

Was there a group of poor closer to the frontier who benefited from migration? By focusing on the inhabitants of the oldest areas we may have missed some poor who were able to migrate more easily. But even so, the fact remains that the majority of the population was concentrated in the older coastal areas, and a considerable number of these could not move to the frontier. And it is precisely for these people that the frontier has been hypothesized to be a safety valve. 